\title{
DIFFERENTIAL DIAGNOSIS OF CHEILITIS - HOW TO CLASSIFY CHEILITIS?
}

\author{
Liborija Lugović-Mihić ${ }^{1,2}$, Kristina Pilipović ${ }^{2}$ Iva Crnarić ${ }^{1}$, \\ Mirna Šitum ${ }^{1,2}$ and Tomislav Duvančić ${ }^{1}$
}
${ }^{1}$ Department of Dermatovenereology, Sestre milosrdnice University Hospital Center, Zagreb, Croatia; ${ }^{2}$ School of Dental Medicine, University of Zagreb, Zagreb, Croatia

\begin{abstract}
SUMMARY - Although cheilitis as a term describing lip inflammation has been identified and recognized for a long time, until now there have been no clear recommendations for its work-up and classification. The disease may appear as an isolated condition or as part of certain systemic diseases/ conditions (such as anemia due to vitamin $\mathrm{B}_{12}$ or iron deficiency) or local infections (e.g., herpes and oral candidiasis). Cheilitis can also be a symptom of a contact reaction to an irritant or allergen, or may be provoked by sun exposure (actinic cheilitis) or drug intake, especially retinoids. Generally, the forms most commonly reported in the literature are angular, contact (allergic and irritant), actinic, glandular, granulomatous, exfoliative and plasma cell cheilitis. However, variable nomenclature is used and subtypes are grouped and named differently. According to our experience and clinical practice, we suggest classification based on primary differences in the duration and etiology of individual groups of cheilitis, as follows: 1) mainly reversible (simplex, angular/infective, contact/eczematous, exfoliative, drugrelated); 2) mainly irreversible (actinic, granulomatous, glandular, plasma cell); and 3) cheilitis connected to dermatoses and systemic diseases (lupus, lichen planus, pemphigus/pemphigoid group, angioedema, xerostomia, etc.).
\end{abstract}

Key words: Cheilitis; Inflammation; Lip Diseases; Actinic Cheilitis; Classification; Dermatitis, Contact

\section{Introduction}

The term cheilitis indicates inflammation of the lip and includes many types, i.e. angular, contact, exfoliative, actinic, glandular, granulomatous, plasma cell cheilitis, simplex, etc. ${ }^{1-5}$. In practice, it is difficult to define readily the precise type of cheilitis, thus proper diagnostic procedures are necessary to determine the exact disease based on its characteristics ${ }^{5}$. For example, angular cheilitis can occur spontaneously or may be related to several precipitating factors (e.g., systemic immune suppression, local irritation and moisture, fungal/bacterial infection). Contact cheilitis can be re-

Correspondence to: Prof. Liborija Lugovic-Mibic, MD, PhD, Department of Dermatovenereology, Sestre milosrdnice University Hospital Center, Vinogradska c. 29, HR-10000 Zagreb, Croatia

E-mail: liborija@gmail.com

Received August 28, 2017, accepted December 12, 2017 lated to the effects of irritants (climatic, mechanical, caustic agents) or allergens (allergic contact cheilitis) ${ }^{5}$. Some types of cheilitis last longer and are persistent, such as chronic actinic cheilitis, granulomatous cheilitis and plasma cell cheilitis. Furthermore, cheilitis can also be seen in various skin or systemic diseases such as lupus erythematosus, lichen planus, atopic dermatitis, etc.

Cheilitis may also be associated with numerous conditions or diseases, e.g., nutritional deficiencies, such as megaloblastic anemia due to vitamin $\mathrm{B}_{12}$ deficiency, anemia due to iron deficiency, oral candidiasis, diabetes $^{2,4-8}$.

Additionally, cheilitis is often divided into particular subtypes with no clear classification having yet been adopted. Considering its duration, some authors refer to acute or chronic cheilitis, whereby there are no 
Table 1. Proposed classification of cheilitis

\begin{tabular}{|l|l|l|}
\hline Mostly reversible & Mostly persistent & $\begin{array}{l}\text { In association with dermatoses and systemic } \\
\text { diseases (common diseases) }\end{array}$ \\
\hline Cheilitis simplex & Actinic cheilitis & Lupus erythematosus \\
Angular/infective cheilitis & Granulomatous cheilitis & Lichen planus \\
Contact/eczematous cheilitis & Glandular cheilitis & Angioedema \\
Exfoliative cheilitis & Plasma cell cheilitis & Pemphigoid/pemphigus \\
Drug related cheilitis & & Xerostomia \\
& & Erythema multiforme \\
& & Crohn's disease \\
& & Sarcoidosis, etc. \\
\hline
\end{tabular}

Table 2. Prominent features of mostly reversible cheilitis

\begin{tabular}{|l|l|l|l|}
\hline $\begin{array}{l}\text { Mostly reversible } \\
\text { cheilitis }\end{array}$ & Occurrence & Related factors & Therapy \\
\hline Cheilitis simplex & Common & $\begin{array}{l}\text { Lip licking } \\
\text { Cold, windy, dry weather }\end{array}$ & $\begin{array}{l}\text { Advice on environmental conditions } \\
\text { Application of lip balms, petroleum } \\
\text { jelly, emollients, topical } \\
\text { corticosteroids, ointments }\end{array}$ \\
\hline $\begin{array}{l}\text { Angular/infective } \\
\text { cheilitis }\end{array}$ & Common & $\begin{array}{l}\text { Infective agents } \\
\text { Immune deficiency (diabetes, HIV) } \\
\text { Mechanical factors } \\
\text { Nutritional deficiencies } \\
\text { (riboflavin, folate, iron, etc) }\end{array}$ & $\begin{array}{l}\text { Elimination of local predisposing } \\
\text { factors } \\
\text { Topical antimycotics, antiseptics, } \\
\text { antibiotics, topical corticosteroids }\end{array}$ \\
\hline $\begin{array}{l}\text { Contact/eczematous } \\
\text { cheilitis }\end{array}$ & Very common & Atopy, contact allergens/irritants & $\begin{array}{l}\text { Topical corticosteroids (low to } \\
\text { medium potency), emollients }\end{array}$ \\
\hline Exfoliative cheilitis & Rare & $\begin{array}{l}\text { Lip licking/picking } \\
\text { Psychological distress } \\
\text { Nutritional deficiencies }\end{array}$ & $\begin{array}{l}\text { Corticosteroids } \\
\text { Psychotherapy } \\
\text { (some cases resolve spontaneously) }\end{array}$ \\
\hline Drug related cheilitis & Rare & Drugs & $\begin{array}{l}\text { Emollients } \\
\text { Drug elimination if possible }\end{array}$ \\
\hline
\end{tabular}

clear criteria ${ }^{2}$. Although there are many recent papers on cheilitis, they are mostly case reports and overviews of therapeutic or diagnostic procedures based on personal experiences and results without specific criteria for classification. Since clear classification has not yet been established, there are no definitive recommendations for diagnosing all different types of cheilitis. Apart from that, cheilitis is also a disease that requires a multidisciplinary approach, which additionally complicates adoption of a classification system. We would like to put forth a classification of cheilitis into three main groups with further particular subtypes (Table 1).

\section{Reversible Cheilitis}

We specify reversible cheilitis (transitory cheilitis of temporary duration) as a distinct category, which includes several subtypes (Table 2).

Cheilitis simplex (chapped lips, common cheilitis, cheilitis sicca) is one of the most common subtypes, presenting as cracked lips, fissures or desquamation of the lips, usually of the lower lip (Fig. 1) $)^{2,7}$. Here frequent lip licking promotes dryness and irritation, ending in separation of the mucosa and cracking. Some authors use a different label for a similarly categorized subtype, lip licking cheilitis, due to lip licking habit or 


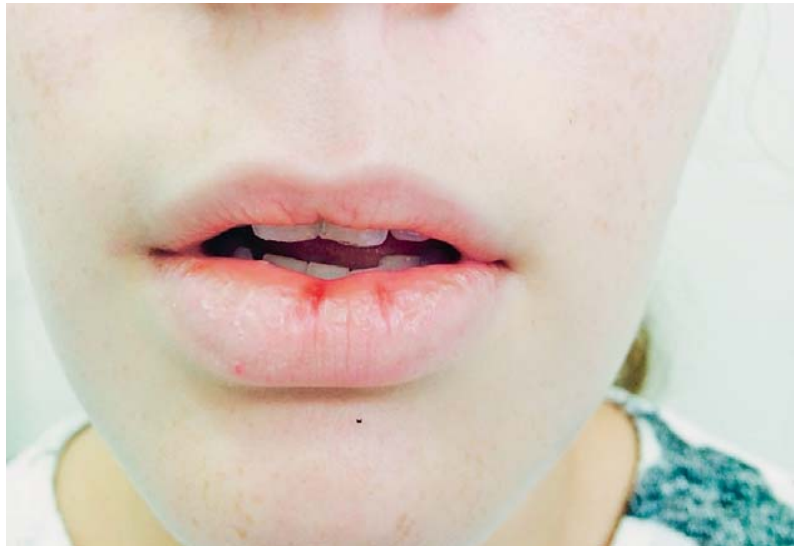

Fig. 1. Cheilitis simplex.

frequent lip retraction into the oral cavity (especially in children with atopic dermatitis) ${ }^{6,7}$. Such licking removes the thin, oily surface film that protects the lips from moisture loss, leading to lip cracking. Lip lesions are also influenced by saliva, the digestive enzymes of which can irritate the lips by extracting moisture and causing evaporation. Some children have the habit of sucking and biting the lower lip, whereby a sharply bordered perioral erythema may occur.

Differential diagnosis includes contact cheilitis, atopic cheilitis, actinic cheilitis, etc. ${ }^{2,4}$. Therapy mostly involves advice on dealing with environmental conditions and the application of lip balms, petroleum jelly, emollients and sometimes topical corticosteroids, mostly low potency ointments.

Angular cheilitis (also termed perleche, cheilosis, or angular stomatitis or angulus infectiosus) typically manifests at the corners of the mouth/lips. The disease is most common in patients with deep wrinkles in lip angles and those who are prone to licking lip corners ${ }^{8}$. Generally, the disease starts during vitamin and mineral deficiencies (B vitamins, iron, zinc, etc.), or is caused by other conditions and diseases (e.g., poorly fitting dentures and drooling, celiac disease $)^{4,6,9}$. An important factor is also saliva production, i.e. increased secretion and drooling, which contributes to the disease. Conversely, during decreased saliva secretion (hyposalivation), dryness promotes cracking and desquamation, as well as the invasion of Candida albicans with the emergence of angular cheilitis inflammation.

Angular cheilitis occurs more commonly in diabetics, in patients with some psychiatric disorders (e.g., lip trauma in bulimics or in anorexia nervosa), during cer-

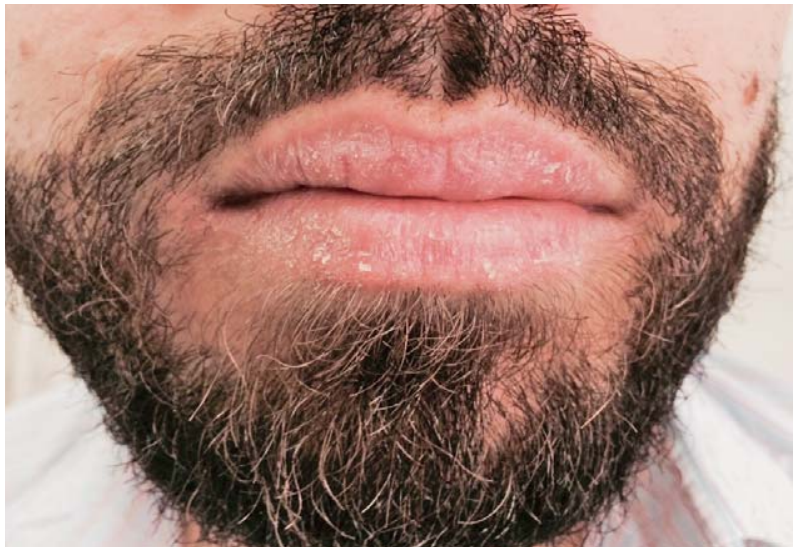

Fig. 2. Contactleczematous cheilitis.

tain drug therapy (e.g., isotretinoin), and somewhat less frequently in primary hypervitaminosis A. It is more common during winter when additional lip licking worsens the condition, and in elderly persons ${ }^{2,5}$. It can occur in patients with inflammatory bowel diseases such as Crohn's disease and ulcerative colitis ${ }^{10}$.

This subtype sometimes develops as part of a group of symptoms, which can include atrophic glossitis, esophageal webs or strictures, and microcytic hypochromic anemia (Plummer-Vinson syndrome) ${ }^{11}$. Concurrence of bacterial or candidal infection (primary or secondary) is common ${ }^{2}$. Children, especially those with atopic dermatitis, are most commonly affected by secondary bacterial infections (staphylococcal and beta-hemolytic streptococcal) on damaged lip corners. Angular cheilitis with secondary infections often occurs also in patients with macroglossia (congenital hypothyroidism and Down syndrome).

Differential diagnosis for this type of cheilitis includes recurrent herpes labialis (if lesions are unilateral) and secondary syphilis (fissured papules at the corners of the lips similar to cheilitis) ${ }^{2,9}$. Therapy includes elimination of predisposing factors and often topical antimycotics, antiseptics, antibiotics, and sometimes corticosteroids.

Contact/eczematous cheilitis is an inflammatory lip reaction caused by the irritating or allergic effects of various substances found in many products such as lipsticks, oral hygiene products (toothpastes), food (e.g., eggs and crustaceans), ointment bases, fragrances, preservatives, antioxidants, dyes, dental materials, musical or occupational instruments, objects put in the mouth daily (e.g., nails, needles, pens), etc. ${ }^{7,12}$. It manifests as 
dryness, scaling, erythema or fissuring, more commonly on the skin than on mucosa (Fig. 2) 2,13,14. This type of cheilitis usually presents in patients with atopic dermatitis ${ }^{15}$. Some authors use the term cheilitis venenata, which specifically indicates contact reaction, most commonly of an allergic type.

There is a broad spectrum of products with common irritants and allergens associated with this subtype. Contact reactions to lipsticks, rubber, leather objects, nail polish substances (e.g., formaldehyde), metals (nickel, cobalt, gold) and topical antibiotics have been shown to be some of the more frequent etiologic factors $^{7,12}$. Reactions to compounds in topical medications and medical products, such as topical antibiotics, virostatic agents, disinfectants, local anesthetics, and sunscreens are also possible. Factitial cheilitis stands out as a distinct subtype of contact cheilitis, usually triggered by a stressful event (possible self-damaging behavior).

Use of the patch test is important to determine these cheilitis causing allergens and to identify the etiologic allergen ${ }^{7}$. Patch testing usually starts with the European baseline series and an overview of the patient's personal cosmetic and topical products, the results of which mostly reveal contact allergens ${ }^{3}$. According to recent patch testing results in patients with non-actinic cheilitis, reported by O'Gorman and Torgerson, the most significant allergens were fragrance mixes, Myroxilon pereirae resin, dodecyl gallate, octyl gallate, and benzoic acid ${ }^{13}$. According to these results, relevant allergens in those patients were fragrances, antioxidants, preservatives and metals (nickel and gold).

Differential diagnosis of contact/eczematous cheilitis includes cheilitis simplex, exfoliative cheilitis, among other types of cheilitis. In the treatment, most important is to exclude etiologic factors. Therapy includes mostly topical corticosteroids of low to medium potency and emollients, which may be combined.

Exfoliative cheilitis indicates lip inflammation, accompanied by constant desquamation, more commonly found on just one lip, usually the lower one. This form occurs a bit less frequently than others, and is common among young people who frequently moisturize their lips, followed by people with vitamin $B_{12}$ or iron deficiency, oral candidiasis, patients with allergies (e.g., to balsam of Peru) or patients with HIV in whom it is often associated with candida infection ${ }^{16-18}$. Exfo- liative cheilitis presents with continuous peeling of the vermilion (lip border). Initially, lips may usually look normal or red, followed by development of a thickened surface layer, which leads to peeling that may be cyclic and proceeds at different rates and at different sites. Sometimes bleeding occurs, later followed by the formation of a hemorrhagic crust. The disease may progress due to several factors, e.g., open-mouthed breathing, lip licking, sucking, picking, or biting, bacterial (Staphylococcus aureus) or yeast (Candida albicans) infection, poor oral hygiene, etc. ${ }^{1}$. Some use the term exfoliative cheilitis as an equivalent to cracked lips, which increases confusion around nomenclature.

Differential diagnosis includes contact cheilitis, cheilitis simplex, etc. Therapy includes topical corticosteroids, topical calcineurin inhibitor, topical Calendula officinalis L., and in some cases psychotherapy ${ }^{1,18}$. Occasionally, lesions resolve spontaneously.

Drug-induced cheilitis refers to lesions due to drug intake, mainly retinoids (e.g., isotretinoin, acitretin) or other medications (topical antibiotics, virostatic agents, lip care products, disinfectants, local anesthetics, creams with protection factors, etc. $)^{19}$. Also possible are drug reactions on skin and lips, in the form of lichenoid reactions, fixed drug eruptions, or changes resembling erythema multiforme ${ }^{2,19}$. Emollients are crucial in the treatment, and discontinuation of the offending agent when possible.

\section{Irreversible Cheilitis}

This group contains a number of chronic cheilitides the verification of which usually calls for biopsy and histology (Table 3).

Actinic (solar) cheilitis (actinic cheilosis, sailor's lip) (Fig. 3) is damage to the lower lip and considered to be a potentially malignant disorder. It is caused primarily by exposure to ultraviolet radiation, thus it is commonly found in certain groups of workers (sailors, agricultural workers, construction workers, beach workers, etc. ${ }^{20-24}$. When erosions are a predominant symptom of the condition, then the term cheilitis abrasiva praecancerosa is used.

This disease occurs mostly in middle-aged, fairskinned men and is a potentially malignant condition that requires biopsies to exclude severe dysplasia or cancer ${ }^{5}$. Clinically, the disease manifests with painless thickening and whitish discoloration at the borders of 
Table 3. Common features of mostly persistent cheilitis

\begin{tabular}{|l|l|l|l|}
\hline $\begin{array}{l}\text { Mostly persistent } \\
\text { cheilitis }\end{array}$ & Occurrence & Related factors & Therapy \\
\hline Actinic cheilitis & Rare & $\begin{array}{l}\text { Sun damage } \\
\text { (outdoor workers, } \\
\text { middle-aged fair-skinned men) }\end{array}$ & $\begin{array}{l}\text { Topical low to medium potency } \\
\text { corticosteroids or 5-fluorouracil, chemical peel } \\
\text { cryotherapy, electrosurgery, vermilionectomy, } \\
\text { immunosuppressants, and surgery }\end{array}$ \\
\hline $\begin{array}{l}\text { Granulomatous } \\
\text { cheilitis }\end{array}$ & Rare & Other granulomatous diseases & $\begin{array}{l}\text { Topical, intralesional (e.g., repeated } \\
\text { triamcinolone acetonide 2.5-5.0 mg/mL) } \\
\text { and systemic corticosteroids and/or antibiotics }\end{array}$ \\
\hline Glandular cheilitis & Very rare & $\begin{array}{l}\text { Smoking, poor oral hygiene, } \\
\text { external influences (sunlight) }\end{array}$ & $\begin{array}{l}\text { Systemic antibiotics and topical, intralesional } \\
\text { or systemic corticosteroids, or surgical excision }\end{array}$ \\
\hline Plasma cell cheilitis & Very rare & Unknown & $\begin{array}{l}\text { Topical and intralesional corticosteroids, } \\
\text { destructive measures, or sometimes even } \\
\text { immunosuppressants }\end{array}$ \\
\hline
\end{tabular}

the lips and skin. Consequently, the lip border (vermilion border) becomes less clear and the lips may gradually become scaly and indurated. The lesions are usually persistent and therefore require biopsy for disease verification. Histopathologically, epithelial atrophy occurs first without cytologic atypia but with solar elastosis of adjacent skin, while later squamous cell carcinoma in situ develops with cytologic atypia, epithelial atrophy or hyperplasia, followed by strands of epithelium growing down into the lamina propria ${ }^{2}$. Therefore, severe dysplasia is characterized by dyskeratosis and keratin pearls, nuclei changes (hyperchromasia, nuclear pleomorphism, anisonucleosis, increased numbers of nucleoli and mitoses, atypical mitoses $)^{25}$. There are recent data that indicate, according to Fourier transform infra red (FT-IR) spectroscopy, that changes in collagen and nucleic acids could be used as molecular biomarkers for malignant transformation ${ }^{20}$.

Differential diagnosis of actinic cheilitis includes a number of diseases, i.e. epithelial dysplasia, squamous cell carcinoma, malignant melanoma, basal cell carcinoma, keratoacanthoma, glandular cheilitis, herpes labialis, discoid lupus erythematosus, etc. Therapy is required to relieve symptoms and to prevent development of squamous carcinoma. It includes topical low to medium potency corticosteroids, 5-fluorouracil, chemical peel, cryotherapy, electrosurgery, vermilionectomy, immunosuppressants, surgery, and also sunscreens (sun protection).

Granulomatous cheilitis (or orofacial granulomatosis) is chronic granulomatous lip swelling of unknown

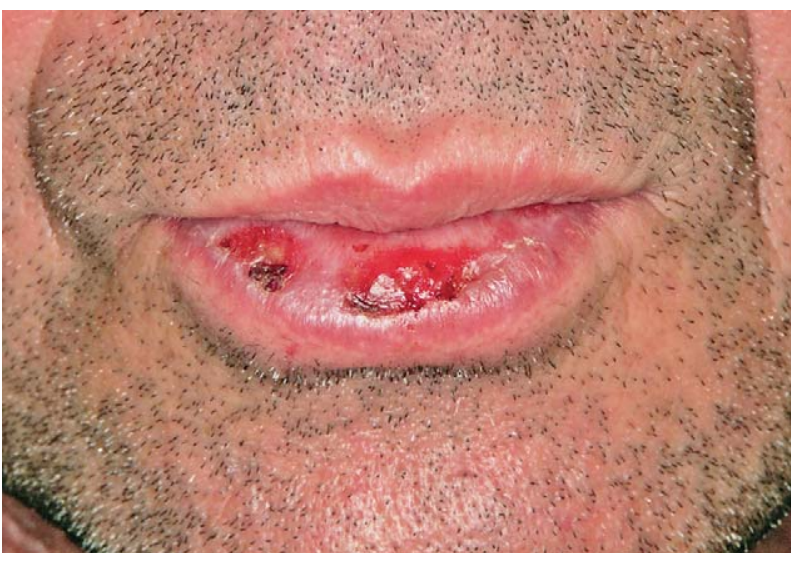

Fig. 3. Actinic cheilitis (a photo from ref. 23; with the author's permission and by the courtesy of Professor Mravak-Stipetic).

etiology, which usually starts in young adults and presents with intermittent or permanent lip swelling (Fig. $4)^{5,26-28}$. The cause of granulomatous cheilitis has not yet been fully elucidated, but current hypothesis holds that random influx of inflammatory cells is responsible. Other proposed related factors of the disease include dietary allergens such as cinnamon and benzoates $^{26}$.

The disease can occur as Miescher's isolated granulomatous cheilitis or with other granulomatous diseases (Crohn's disease, sarcoidosis and MelkerssonRosenthal syndrome $)^{5,7}$. Melkersson-Rosenthal syndrome is characterized by granulomatous cheilitis, facial palsy and plicated tongue, although only one or 


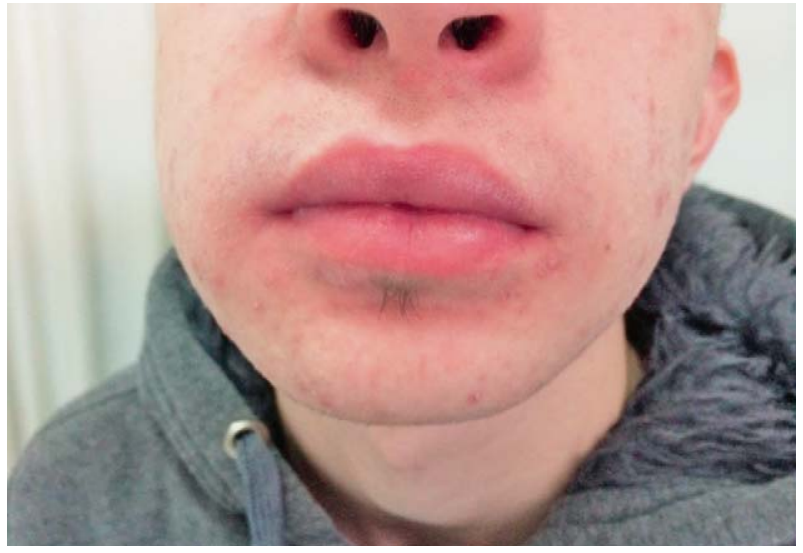

Fig. 4. Granulomatous cheilitis.

two symptoms usually appear (the complete triad of symptoms occurs in only $25 \%$ of patients). Granulomatous cheilitis accompanied by persistent intraoral aphthae may suggest Crohn's disease.

Histologically, granulomatous cheilitis is characterized by chronic inflammatory reaction consisting of lymphocytes, histiocytes, and tuberculoid granuloma having epithelioid cells and Langerhans giant cells ${ }^{27}$. Histology from early lesions shows only edema and sparse infiltrate, while later there is a more intense infiltrate with small sarcoidal granulomas. Differential diagnosis of granulomatous cheilitis includes elephantiasis nostras, forms of recurrent erysipelas and herpes simplex, macrocheilia, angioedema, tuberculosis, glandular cheilitis, contact cheilitis, Ascher's syndrome, organized hematoma, sarcoidosis, among others ${ }^{14,26,27}$. Therapy may include topical, intralesional (e.g., triamcinolone acetonide $2.5-5.0 \mathrm{mg} / \mathrm{mL}$ for several months or longer) and systemic corticosteroids/antibiotics, dietary modifications and surgery, although treatment is not always necessary ${ }^{26,28}$.

Glandular cheilitis is a rare chronic inflammatory condition of the minor salivary glands, predominantly of the lower lip ${ }^{2,29}$. The disease was first described by von Volkmann under the designation 'cheilitis glandularis apostematosa' or 'myxadenitis labialis' ${ }^{29}$. Etiologic factors considered to be involved are smoking, poor oral hygiene, chronic exposure to external influences (sunlight, wind, tobacco), bacterial infection and congenital predisposition.

Variants are cheilitis simplex and cheilitis apostematosa. The simplex form usually manifests as tiny red papules, especially on the lower lip, with a possible, gradually evolving lip edema (macrocheilia). It can be related to chronic irritation of the lower lip (actinic, atopic or mechanical), with potential secondary causes being chronic sialadenitis, ductal metaplasia and fibrosis. Glandular apostematosa cheilitis is a secondary staphylococcal infection of the minor salivary glands, which presents with crust and pus drainage accompanied by pain.

Histopathology is nonspecific with possible salivary gland hyperplasia, duct ectasia, and dermal inflammatory infiltrate (lymphocytes, plasma cells, histiocytes). Differential diagnosis includes other forms of cheilitis and squamous cell carcinoma. Management includes histopathologic analysis, identification of etiologic factors, and attempts to alleviate or eradicate these factors. Therapy includes systemic antibiotics and topical, intralesional or systemic corticosteroids, or surgical excision.

Plasma cell cheilitis is a very rare type of lip inflammation of unknown etiology characterized histologically by diffuse plasma cell infiltration in dermis ${ }^{27,30}$. Clinically, it presents as a circumscribed and flat to slightly raised eroded area of the lip, or as erythematous-violaceous, ulcerated and asymptomatic plaques which evolve slowly. Histology includes a band-like infiltrate of plasma cells in the upper dermis, with possible capillary dilation, erythrocyte extravasation, hemosiderin deposits, and mild epidermal spongiosis. Differential diagnosis includes actinic cheilitis, allergic contact cheilitis, lichen planus, etc. Therapy may include topical and intralesional corticosteroids, topical calcineurin inhibitors, destructive treatment methods, or sometimes even immunosuppressants ${ }^{30}$.

\section{Cheilitis Associated with Skin Diseases and Systemic Diseases}

The chronic discoid form of lupus erythematosus can sometimes encompass lip changes/lesions, which present as diffuse cheilitis, spreading usually above the vermilion zone. Subacute cutaneous lupus erythematosus rarely includes oral lesions, manifesting with sharply bordered, slightly atrophic erythema of oral mucosa or, as in severe cases, a diffuse erythematous, scar plaque, which extends beyond the vermilion. Lip changes in systemic lupus erythematosus may present as bordered or diffuse erythema, purpuric maculae, erosions or ulcerations, or patients may have oral ulcerations, which 


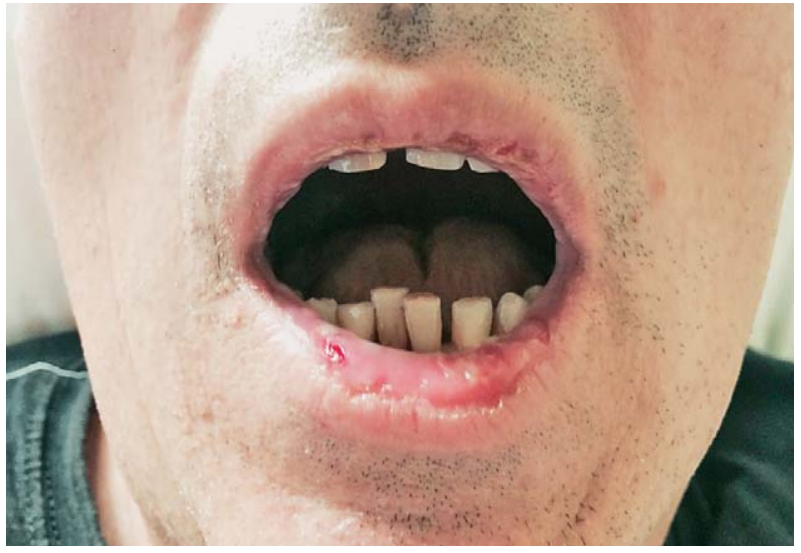

Fig. 5. Lip lesions/cheilitis in association with pemphigus vulgaris.

are one of the major criteria for systemic lupus erythematosus diagnosis ${ }^{31}$. Generalized rash in acute lupus can also affect the lips in some cases. Differential diagnosis of lupus erythematosus on the lips may include allergic contact dermatitis, actinic cheilitis, lichen planus, psoriasis, erythema multiforme, pemphigus vulgaris, squamous cell carcinoma, etc.

Lichen planus as a chronic mucocutaneous disease occurs in 6\% of cases on the lips in the form of reticular, striatus or annular Wickham's striae, irregular (patchy) erythema and erosions, especially of the lower $\operatorname{lip}^{32}$. Differential diagnosis includes lichenoid drug reactions (e.g., to antiinflammatory medications, angiotensin-converting enzyme inhibitors, antimalarials), lichenoid contact dermatitis (e.g., to amalgam and other dental materials), discoid lupus erythematosus, etc.

Angioedema manifests often on the lips and is mostly allergic ${ }^{19,33}$. It is one of the most common causes of transient lip swelling, while macrocheilia describes permanent swelling of one or both lips.

Manifestations of bullous diseases are also possible on the lips, especially in pemphigus vulgaris (Fig. 5), an autoimmune mucocutaneous blistering disease the initial manifestations of which often are oral lesions (50\% to $70 \%$ of cases), mostly erosions. Similar changes may be seen in the pemphigoid group ${ }^{34}$. Sometimes it initially presents with single persistent lower lip lesions without progressing to other location. Both the pemphigus and pemphigoid workups are complex and include histopathologic and immunofluorescent diagnostics.

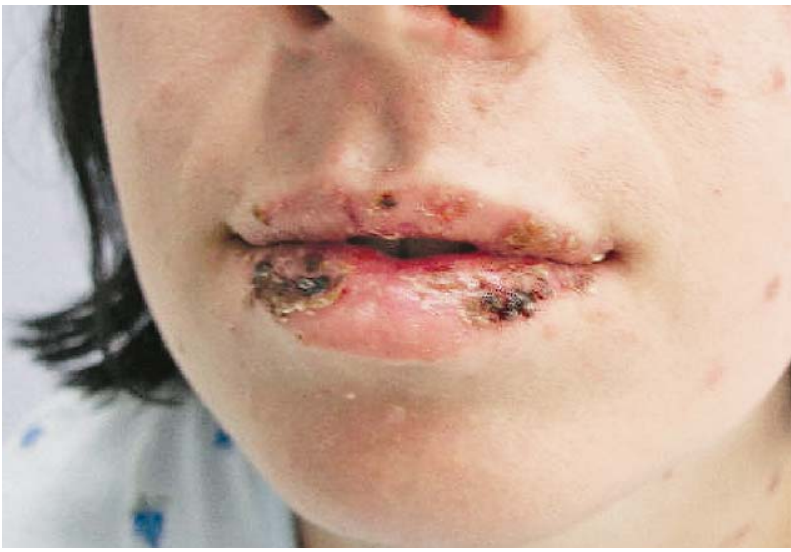

Fig. 6. Lip lesions/cheilitis in association with erythema multiforme.

Lips may also be affected as part of other dermatoses, e.g., erythema multiforme (Fig. 6), atopic dermatitis, herpes simplex, Stevens-Johnson syndrome, and toxic epidermal necrolysis, often resulting in the formation of erosions and crusts ${ }^{2,19}$.

\section{Discussion}

Cheilitis is a term describing lip inflammation of various etiologies, which occurs relatively often. The disease may appear as an isolated condition or as part of certain systemic diseases or conditions. It may be part of a clinical picture or an accompanying condition. Cheilitis can co-occur with many conditions including anemia, oral candidiasis, atopy, contact reaction to an irritant or allergen (e.g., to cosmetics), drug intake (e.g., retinoids), etc. Generally, the most commonly reported forms in the literature are angular, contact (allergic and irritant), actinic, exfoliative, etc. ${ }^{2,21-24}$. As contact cheilitis can be related to the effects of irritants or allergens, it should be investigated with thorough history taking. Some lip lesions require biopsies, such as chronic actinic cheilitis (to examine for severe dysplasia or cancer) or granulomatous cheilitis (to confirm the diagnosis) , $22,35^{\text {. }}$.

When managing and diagnosing cheilitis, complete examination of the patient's oral cavity, skin and other mucosae is required, along with appropriate diagnostic procedures. When approaching patients, several factors need to be taken into account, particularly patient general medical history (e.g., existence of diabetes, atopy, immunosuppression), exposure to external 
Table 4. Common diagnostic parameters/procedures related to specific cheilitis group

\begin{tabular}{|c|l|l|}
\hline Mostly reversible & $\begin{array}{l}\text { Mostly persistent } \\
\text { (irreversible) }\end{array}$ & $\begin{array}{l}\text { In association with } \\
\text { dermatoses and } \\
\text { systemic diseases }\end{array}$ \\
\hline - History data: drug intake, habits (lip licking, biting, sucking, picking, & $\begin{array}{l}\text { Persistent lesions } \\
\text { require biopsy } \\
\text { hygiene, open-mouther conditions (cold, hot, windy, dry weather), age, poor oral } \\
\text { and } \\
\text { histopathologic } \\
\text { analysis }\end{array}$ & $\begin{array}{l}\text { Diagnostic } \\
\text { work-up according } \\
\text { to suspected disease }\end{array}$ \\
$\begin{array}{l}\text { (e.g., diabetes, psychiatric disorders, atrophic glossitis, dysphagia, } \\
\text { - Deficiencies, e.g., B vitamins (B2, B3, B5, B7, B12), iron, zinc, etc., } \\
\text { malnutrition (e.g., celiac disease), or hypervitaminosis (e.g., vitamin A) }\end{array}$ & \\
- Atopy (in patient and family): total IgE, allergic skin tests \\
$\begin{array}{l}\text { (patch test, prick test), in vitro allergic tests } \\
\text { - Oral and skin swabs (mycotic and bacterial; e.g., yeast infection such as } \\
\text { Candida albicans or bacterial infection such as Staphylococcus aureus } \\
\text { or Streptococcus) }\end{array}$ & \\
\hline
\end{tabular}

factors (e.g., weather conditions), the possibility of vitamin or mineral deficiencies, undesirable habits (lip licking, frequent sun exposure, lip contact with various substances), etc. (Table 4). It is also important to know whether the lesions are persistent or whether they are reversible since irreversible cheilitis demands a different treatment approach.

Until now, there have been no clear recommendations for the workup and classification of cheilitis although cheilitis has been identified and recognized for quite a long time. In the literature on cheilitis, varied nomenclature is used and subtypes are grouped and named differently. Braun Falco et al., for instance, classify cheilitides as angular, simplex, actinic (acute/ chronic), glandularis, granulomatous and plasma cell cheilitis $^{2}$. According to the PUBMED/MEDLINE database, the total number of published articles retrieved by the keywords 'cheilitis classification' does not exceed 14 while those searched by the keywords 'differential diagnosis' does not exceed 120. Regarding newly published articles, most are case reports and overviews of therapeutic or diagnostic procedures based on personal experiences and results. Taking into account our experience and that of other authors, we are offering an overview of the most important cheilitis types. According to Oakley, there are few cheilitis groups: (1) cheilitis due to infection or skin conditions (angular, granulomatous, orofacial granulomatosis, Crohn's skin disease, actinic, exfoliative, glandular, lichenoid, cutaneous lupus erythematosus); (2) cheilitis due to an allergy, toxin, medication or injury (eczematous cheilitis, allergic contact cheilitis, pigmented contact cheilitis, cheilitis in musicians, contact reactions to lipsticks and other lipcare products, irritant and allergic contact dermatitis, smoking and its effects on the skin, sunburn, isotretinoin treatment, acitretin treatment, denture stomatitis); and (3) cheilitis due to nutritional deficiency (iron, vitamin B) ${ }^{4}$.

According to our experience and clinical practice, we suggest the classification of cheilitis as (1) mainly reversible (transient); (2) mainly irreversible (persistent); and (3) cheilitis associated with particular dermatoses and systemic diseases (Table 1). This kind of classification would be based upon primary differences in the course and etiology of individual groups of cheilitides. Thus, the group of reversible cheilitides (of temporary duration) includes mostly milder types of cheilitis, which usually significantly regress following elimination of the etiologic factor. Rarely they are persistent and resistant to treatment. Cheilitides of the irreversible type have a more lasting character, which usually requires histologic workup (biopsy). Finally, the third class of cheilitides encompasses inflammatory lip changes related to specific skin or systemic diseases.

There are no precise epidemiologic data on the prevalence and incidence of each cheilitis type either. We can only give data on its frequency based on our clinical experience. The approach to cheilitis needs to be interdisciplinary and should include dermatolo- 
gists, oral pathologists, ENT specialists, and also specialists in internal medicine and psychiatry $\mathrm{y}^{1,6,7,10,19,26,36-39}$. Professionals from different specialties can come to a conclusive diagnosis by additional specific diagnostics. It is important to have in mind that the approach to a patient with cheilitis includes, apart from dermatologic conditions, other related diseases such as some granulomatous diseases (Crohn's disease, sarcoidosis and Melkersson-Rosenthal syndrome), nutritional deficiencies, and gastrointestinal diseases (e.g., celiac disease, Plummer-Vinson syndrome) (Table 4).

We find that our classification would mean considerable benefit for patients and hasten treatment since it would simplify recognition and diagnosis, thereby ensuring appropriate treatment. We found that the crucial step is getting detailed medical history of the patient with all possible information on the potential mitigating factors. Complete medical history, clinical picture and appropriate diagnostic workup are the key factors in recognizing the right type of cheilitis and of its successful treatment.

\section{References}

1. Almazrooa SA, Woo SB, Mawardi H, Treister N. Characterization and management of exfoliative cheilitis: a single-center experience. Oral Surg Oral Med Oral Pathol Oral Radiol. 2013;116:485-9. doi: 10.1016/j.oooo.2013.08.016.

2. Bork K. Diseases of the lips and mouth. In: Burgdorf WHC, Plewig G, Wolf HH, Landthaler M, eds. Braun-Falco's Dermatology, $3^{\text {rd }}$ edn. Berlin: Springer-Verlag, 2009; p. 1081-107.

3. Collet E, Jeudy G, Dalac S. Cheilitis, perioral dermatitis and contact allergy. Eur J Dermatol. 2013;23:303-7. doi: 10.1684/ ejd.2013.1932.

4. Dermnet New Zealand all about the skin [Internet]. New Zealand: Dermatological Society. [cited 2017 Aug 26]. Cheilitis; [about 3 screens]. Available from: https://www.dermnetnz.org/ topics/cheilitis/

5. Samimi M. Cheilitis: diagnosis and treatment. Presse Med. 2016;45:240-50. doi: 10.1016/j.lpm.2015.09.024.

6. $\mathrm{Lu} \mathrm{S}, \mathrm{Wu} \mathrm{H}$. Initial diagnosis of anemia from sore mouth and improved classification of anemias by $\mathrm{HCV}$ and RDW in 30 patients. Oral Surg Oral Med Oral Pathol Oral Radiol Endod. 2004;98:679-85. doi:10.1016/S1079210404000599.

7. Bakula A, Lugović-Mihić L, Šitum M, Turčin J, Šinković A. Contact allergy in the mouth: diversity of clinical presentations and diagnosis of common allergens relevant to dental practice. Acta Clin Croat. 2011;50:553-61.

8. Uptodate [Internet]. Alphen aan den Rijn (NL): Wolters Kluwer. [cited 2017 Aug 26]. Cheilitis; [about 10 screens]. Available from: https://www.uptodate.com/contents/cheilitis
9. Park KK, Brodell RT, Helms SE. Angular cheilitis. Part 2: Nutritional, systemic, and drug-related causes and treatment. $\mathrm{Cu}-$ tis. 2011;88:27-32.

10. Muhvić-Urek M, Tomac-Stojmenović M, Mijandrušić-Sinčić B. Oral pathology in inflammatory bowel disease. World J Gastroenterol. 2016;22:5655-67. doi: 10.3748/wjg.v22.i25.5655.

11. Samad A, Mohan N, Balaji RV, Augustine D, Patil SG. Oral manifestations of Plummer-Vinson syndrome: a classic report with literature review. J Int Oral Health. 2015;7:68-71.

12. Budimir V, Brailo V, Alajbeg I, Vučićević Boras V, Budimir J. Allergic contact cheilitis and perioral dermatitis caused by propolis: case report. Acta Dermatovenerol Croat. 2012;20(3): 187-90.

13. O'Gorman SM, Torgerson RR. Contact allergy in cheilitis. Int J Dermatol. 2016;55:386-91. doi: 10.1111/ijd.13044.

14. Schena D, Fanntuzi F, Girolomoni G. Contact allergy in chronic eczematous lip dermatitis. Eur J Dermatol. 2008; 18:688-92. doi: 10.1684/ejd.2008.0520.

15. Lugović L, Lipozenčić J, Jakić-Razumović J. Atopic dermatitis: immunophenotyping of inflammatory cells in skin lesions. Int J Dermatol. 2001;40:489-94. doi: 10.1046/j.1365-4362.2001. 01203.

16. Mani SA, Shareef BT. Exfoliative cheilitis: report of a case. J Can Dent Assoc. 2007;73:629-32.

17. Reichart PA, Weigel D, Schmidt-Westhausem A, Pohle HD. Exfoliative cheilitis (EC) in AIDS: association with Candida infection. J Oral Pathol Med. 1997;26:290-3.

18. Roveroni-Favaretto LH, Lodi KB, Almeida JD. Topical Calendula officinalis $\mathrm{L}$. successfully treated exfoliative cheilitis: a case report. Cases J. 2009;23:9077. doi: 10.1186/1757-1626-2-9077.

19. Schwarz I, Bokanovic D, Aberer W. Mucosal diseases from an allergological perspective. Hautarzt. 2016;67:780-5. doi: 10.1007/s00105-016-3866-3.

20. das Chagas E Silva de Carvalho LF, Pereira TM, Magrini TD, Cavalcante AS, da Silva Martinho H, Almeida JD. Optical diagnosis of actinic cheilitis by infrared spectroscopy. Photodiagnosis Photodyn Ther. 2016;16:27-34. doi: 10.1016/j.pdpdt.2016.07.013.

21. Martins PR, Filho, Silva LC, Piva MR. The prevalence of actinic cheilitis in farmers in a semi-arid northeastern region of Brazil. Int J Dermatol. 2011;50:1109-14. doi: 10.1111/j.1365-4632.2010 .04802 .

22. Muthukrishnan A, Bijai Kumar L. Actinic cheilosis: early intervention prevents malignant transformation. BMJ Case Rep. 2017 Mar 20;2017. pii: bcr2016218654. doi:10.1136/bcr-2016-218654.

23. Lugović-Mihić L, Šitum M, et al. Bolesti kože s promjenama na licu i usnoj šupljini. Zagreb: Medicinska naklada; 2017. (in Croatian)

24. Souza Lucena EE, Costa DC, Silveira EJ, Lima KC. Prevalence and factors associated to actinic cheilitis in beach workers. OralDis.2012;18:575-9.doi:10.1111/j.1601-0825.2012.01910. 
25. Pilati S, Bianco BC, Vieira D, Modolo F. Histopathologic features in actinic cheilitis by the comparison of grading dysplasia systems. Oral Dis. 2017;23(2):219-24. doi: 10.1111/odi.12597.

26. Critchlow WA, Chang D. Cheilitis granulomatosa: a review. Head Neck Pathol. 2014;8:209-13. doi: 10.1007/s12105-013-0488-2.

27. Sarkar S, Ghosh S, Sengupta D. Clinically granulomatous cheilitis with plasma cells. Indian Dermatol Online J. 2016;7:96-8. doi: 10.4103/2229-5178.178094.

28. Banks T, Gada S. A comprehensive review of current treatments for granulomatous cheilitis. Br J Dermatol. 2012; 166:934-7. doi: 10.1111/j.1365-2133.2011.10794.

29. Friedrich RE, Löning T. Cheilitis glandularis: case report with respect to immunohistochemical findings. GMS Interdiscip Plast Reconstr Surg DGPW. 2016 Jan 20;5:Doc04. doi: 10.3205/iprs000083.

30. Yamaguchi Y, Nishie W, Ito T, Shimizu H. Plasma cell cheilitis successfully treated with topical calcineurin inhibitors. Eur J Dermatol. 2016;26(6):609-10. doi: 10.1684/ejd.2016.2858.

31. Chan WMM, Pang SM, Ng SK. Severely crusted cheilitis as an initial presentation of systemic lupus erythematosus. Indian J Dermatol. 2017;62(4):440. doi: 10.4103/ijd.IJD_559_16.

32. Peršić S, Lugović-Mihić L, Budimir J, Šitum M, Bulat V, Krolo I. Oral lesions in patients with lichen planus. Acta Clin Croat. 2008;47(2):91-6.
33. Duvančić T, Lugović-Mihić L, Brekalo A, Šitum M, Šinković A. Prominent features of allergic angioedema on oral mucosa. Acta Clin Croat. 2011;50(2) 531-8.

34. Budimir J, Lugović Mihić L, Šitum M, Bulat V, Peršić S, Tomljanović-Veselski M. Oral lesions in patients with pemphigus vulgaris and bullous pemphigoid. Acta Clin Croat. 2008;47(1)13-8.

35. Magister MJ, Ghaffari G. Granulomatous cheilitis mimicking angioedema. Cutis. 2017;99(5):16-8.

36. Lugović-Mihić L, Ljubešić L, Mihić J, Vuković-Cvetković V, Šitum M. Psychoneuroimmunologic aspects of skin diseases. Acta Clin Croat. 2013;52(3):337-45.

37. Kelava N, Lugović-Mihić L, Duvančić T, Romić R, Šitum M. Oral allergy syndrome - the need of a multidisciplinary approach. Acta Clin Croat. 2014;53(2):210-9.

38. Panico R, Piemonte E, Lazos J, Gilligan G, Zampini A, Lanfranchi $\mathrm{H}$. Oral mucosal lesions in anorexia nervosa, bulimia nervosa and EDNOS. J Psychiatr Res. 2018;96:178-82. doi: 10.1016/j.jpsychires.2017.09.022.

39. Charpentier C, Kottler D, Fite C, Pelletier AL, Deschamps L, Descamps V. A surprising granulomatous cheilitis. Gastroenterology. 2017 Jul 13. pii: S0016-5085(17)35880-8. doi: 10.1053/j.gastro.2017.07.005.

Sažetak

\section{DIFFERENCIJALNA DIJAGNOZA HEILITISA - KAKO KLASIFICIRATI HEILITIS?}

\section{Lugović-Mihic, K. Pilipović, I. Crnarić, M. Šitum i T. Duvančić}

Iako je heilitis kao pojam koji opisuje upalu usnica bio zapažen i prepoznat već prije dugo vremena, dosad nema jasnih preporuka za dijagnostički postupak i klasifikaciju. Bolest se može javiti kao izolirano stanje ili kao dio nekih bolesti/stanja poput anemije (zbog nedostatka vitamina $B_{12} \mathrm{i}$ željeza) ili lokalne infekcije (npr. herpes i oralna kandidijaza). Heilitis također može biti simptom kontaktne reakcije na iritans ili alergen te može biti potaknut izlaganjem suncu (aktinički heilitis) ili uzimanjem lijeka (osobito retinoida). Općenito se najčešće spominju oblici angularni, kontaktni (alergijski i iritativni), aktinički, glandularni, granulomatozni, eksfolijativni i plazmacelularni heilitis. Ipak se u literaturi o heilitisu rabi različita nomenklatura pa su podtipovi grupirani i nazvani različito. Prema našem iskustvu i kliničkoj praksi predlažemo klasifikaciju temeljenu na primarnoj razlici u trajanju i etiologiji pojedinih skupina heilitisa: 1. pretežno reverzibilni (simpleks, angularni/infektivni, kontaktni/ekcematoidni, eksfolijativni, lijekom potaknuti), 2. pretežno ireverzibilni (aktinički, granulomatozni, glandularni, plazmacelularni) i 3. heilitisi povezani s dermatozama i sustavnim bolestima (lupus, lihen planus, skupina pemfigusa/pemfigoida, angioedem, kserostomija itd.).

Ključne riječi: heilitis; upala; usna, bolesti; aktinički heilitis; klasifikacija; dermatitis, kontaktni 